\begin{tabular}{|c|l|}
\hline \multirow{2}{*}{$\begin{array}{c}\text { TOURISM } \\
\text { AND }\end{array}$} & Journal of Tourism\&Management Research \\
MANAGEMENT & ISSN: 2149-6528 \\
AN NTIERNATONAL JOURNAL & 2021 Vol. 6, Issue.1 \\
& http://ottomanjournal.com/index.html \\
\hline
\end{tabular}

\title{
A Study on the Push-Pull Factors Related to Recreational Travel
}

\begin{abstract}
This study aims to reveal the extent to which the individuals traveling to Kars with the Orient Express give importance to recreational activities and Internal and External travel motivations in their destination choice, and whether the revealed significance levels differed according to various variables. The sample group in the study was formed by choosing the individuals who preferred the Orient Express and Kars Destination between January and February based on the principle of voluntary participation by using the appropriate sampling method. A total of 432 individuals were reached in the study $(n=432)$. Percentage and frequency descriptive statistical methods were used to determine the distribution of personal information, and skewness and kurtosis values of the data were checked to determine whether the data showed normal distribution. As a result of the analyses made, it was determined that the data had a normal distribution. In the statistical analysis of the data, besides descriptive statistics, t-test, ANOVA, Tukey HSD multiple comparison test, and correlation analyses were used for determining significant groups $(\alpha=0.05)$. As a result, no significant difference was found between the importance given to recreational activities in the destination choice and the demographic characteristics of individuals traveling to Kars on the Orient Express journey. It was revealed that the internal travel motivations differed in all the specified demographic characteristics. Besides, it was found that pulling travel motivations did not differ significantly only in terms of the income variable of individuals and there were significant differences in terms of other demographic variables.
\end{abstract}

Keywords: Railway, recreation, travel motivation, push and pull factors, orient express.

Jel Codes: L84, L92, N75.

Submitted: 29.11.2020; Accepted: 15.04.2021

Alper Kaya, Research Assistant. (Corresponding Author). Recreation Management Department, Faculty of Tourism, University of Necmettin Erbakan, Turkey. https://orcid.org/0000-0002- 0364-4122

E-mail: alper.kaya.gazi@gmail.com

Mehmet Demirel, Associate Professor. Recreation Management Department, Faculty of Tourism, University of Necmettin Erbakan, Turkey. https://orcid.org/0000-0003-1454-022X

E-mail: mehmetdemirel78@gmail.com 


\section{Introduction}

Recently, it has been observed that the sedentary or less active life brought about by intensive work has increased all over the world. In addition to sedentary life, it is seen that anti-social lifestyle is becoming more common among individuals. It is known that individuals are directed to various recreational activities in order to get rid of anti-social and sedentary lifestyle (Gözen, 2019). Recreation has enabled both life satisfaction and quality of life to increase (Demirel, et.al., 2021). Accepting recreational activities as a necessity has increased the diversity of the sector (Aksu, 2020). In addition to recreational activities, the participation of individuals in tourism activities is also facilitated. In addition to the attractive recreational activities, tourism activities enable individuals to socialize, increase their knowledge and increase economic returns in national or international terms.

Tourism is primarily evaluated in three parts as youth tourism, middle age tourism and third age tourism according to the age of the participants. Youth tourism is the participation of people aged 15-24 in tourism activities. Young people tend to travel more than middle age and third age groups. Younger age groups participating in tourism activities are adventureoriented compared to other age groups and do not seek comfort in the destination they have reached (Kozak et al., 2015). The phenomenon of youth tourism is the subject of social and cultural tourism factors. It is one of the important tools of national and international peace and tolerance (Emre, 1992). Tourism is one of the largest sectors in the world, which is effective in the formation of a peaceful and tolerant society. Tourist activities continue to develop with various travel and destination trends. One of the types of tourism that contributes the most to these developments and advancements is youth tourism activities, which provide significant economic and social benefits to the destination (Syzdykova, 2018). One of the most important purposes of young tourists traveling is stated as getting to know the local. 55\% of the youth stated that their motivation to travel is getting to know the local people. $46 \%$ stated that they travel to get to know and experience the daily life in the destination, and $43 \%$ stated that they travel to increase their knowledge about the destination. (Y1lmaz, 2018). For the development of tourism nationally and internationally, governments and local administrations have ensured that transportation is discounted for young people and aimed to increase the participation of young people in touristic activities.

Today, the concept of travel is becoming increasingly widespread with developing technological breakthroughs. With the emergence of transportation diversity, individuals can reach their destination by using the transportation type they desire. With the development of internet technology, the widespread use of social media, advertisements, and promotions, travel destinations can become more renowned and preferable (Doğaner and Armağan, 2018). People may tend to travel to use their free time better. Railway travel can sometimes be preferred because it is economical and safer than other types of transportation. Railway transportation, which has been continuously developing in the historical process, can demonstrate the development level of a country to foreign countries. Since its establishment, the Republic of Turkey has ascribed great importance to railway transportation and a network of railways covering the entire homeland and has considered railroads necessary to reach the level of an advanced civilization. This strategy was successfully implemented in the first years of the Republic and thereafter (Aydemir, 1993).

People can travel for various reasons such as escaping from busy working life, relaxing, exploring new places and cultures, and experiencing adventure, etc., and they can participate in recreational activities in the destinations they travel to (Demirci Orel and Yavuz, 2003). For example, the presence of natural beauties and archaeological sites and museums in the region, places where indoor and outdoor recreational activities can be performed, activities in which people can participate actively or passively can increase the preference of that destination. In addition to the natural appeal of a destination, the cultural attractions it embodies can affect the preference of the region (Atsiz and Kizılırmak, 2017). Recreation 
generally includes activities in which individuals participate voluntarily in their leisure time. It is known that these activities have a very wide structure when considered within the scope of tourism and travel. Recreational activities, festivals and activities organized in a destination contribute to the formation of the image of the destination. The attractive elements that the destination has and offers significantly affect development of the destination (Ercan and Civelek, 2020).

Based on the information provided, the purpose of this research is to ensure that individuals traveling to Kars with the Orient Express; to reveal the importance they attach to recreational activities, intrinsic and extrinsic travel motivations in destination selection. In addition, it was aimed to examine the importance given to recreational activities, intrinsic and extrinsic travel motivations in destination selection in terms of various demographic variables.

\section{Literature Review}

\subsection{The Orient Express and Kars Destination}

The Orient Express travels between the cities of Ankara, Kirıkkale, Sivas, Erzincan, Erzurum and Kars. The Orient Express departing from Ankara at 18:00 serves every day of the year. The total length of the railway line between Ankara and Kars is $1,310 \mathrm{~km}$. The Express can reach Kars in 24 hours in general (Ery1lmaz and Yücetürk, 2018; Korkusuz, 2019). The train has dining, pullman and coated couchette cars. The number of these cars can vary according to demand. It is stated in the 2017 annual activity report of The Republic of Turkey State Railways (TCDD) that the Orient Express received more demand than in previous years (in the winter period), and that it was in high demand from various groups such as student groups, photography and hiking groups as well as various travel businesses (TCDD, 2018).

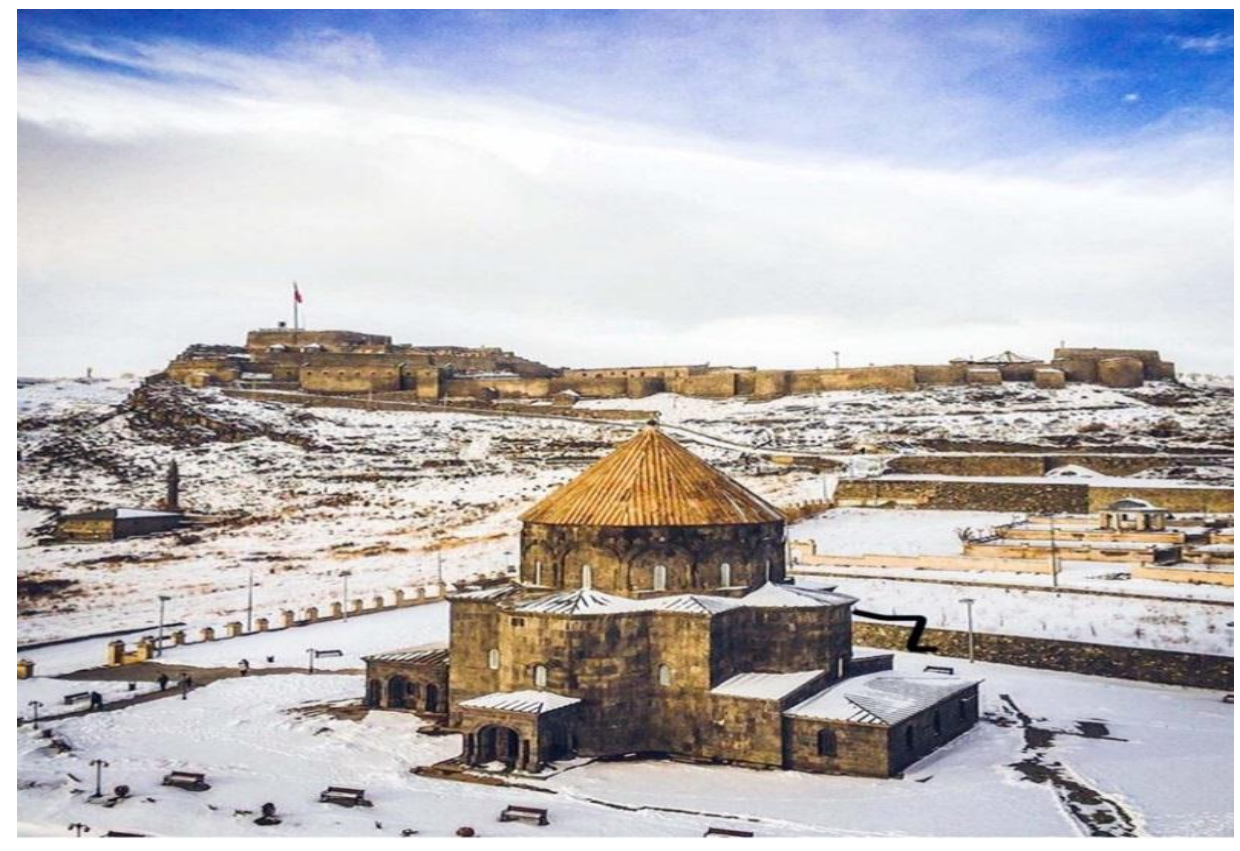

Figure 1: Kars Castle and Kümbet Mosque (12 Apostles Church).

Source: (www.karstanhavadis.com).

Located in the Eastern Anatolia Region, Kars is one of Turkey's border provinces. With a total surface area of $9,442 \mathrm{~km}^{2}$, the city covers $1.2 \%$ of the country's lands (Altunsoy, 2005). Dominated by a harsh and continental climate, Kars province hosted various civilizations and states such as Urartu, Saka, Byzantine, Seljuk, İlhanl1, Altınordu, Akkoyunlu states and Ottoman and Russian empires (Kırzıoglu, 1953). This city, which historically hosted 
important civilizations, is one of the major touristic destinations that attracts attention with its touristic, cultural, historical as well as its natural beauties. Especially Ottoman and Russian architectural works are dominant in the city (Demir, 2013). In addition to Ottoman and Russian architectural works, there are various natural areas such as Sarıkamış Allahuekber Mountains National Park, Sarıkamış Ski Center, Çıldır Lake where individuals can participate in various activities, Kuyucuk Lake Bird Watching Area, Kars Stream used for rafting in Kars. There are also important archaeological sites such as Ani Ruins and Borluk Valley, which has been designated as an area under protection. In terms of activities, various activities such as Sarıkamış Winter Games Festivals, internationally organized Golden Goose Film Festival, Cheese Tasting Festival are organized. It has museums such as Kars Museum and the Caucasian Front War History Museum and important historical castles such as Kars Castle and the Maiden Castle. In addition to these, it has various martyrs memorial and monuments as important events and wars took place here during the First World War (Korkusuz, 2019).

\subsection{Push and Pull Factors}

Various theories have been developed to measure travel motivations. One of them is the theory that was introduced by Dann (1977) and later developed by Crompton (1979), which deals with the pushing and pulling factors in individuals' travels. Many researchers have used this theory in various studies in ensuing processes (Antara and Prameswari, 2018; Baloğlu and Uysal, 1996; Jang and Wu, 2006; Khuong and Ha, 2014; Kim, Lee and Klenosky, 2003; Li and Qi, 2019; Said and Maryono, 2018; Subadra et al., 2019). The push factors consist of internal and intangible elements that make people want to travel. They can also be described as individual factors independent of the destination, creating a desire to meet the travel need or as social and psychological factors. Pull factors are related to the destination. Pull factors are about the attractiveness of the destination for the individual traveling. Tourists form their motivations related to pull factors according to their interests, expectations and perceptions about the destination they choose to go to (Antara and Prameswari, 2018; Keleş, 2015).

Dann (1977) mentioned two types of tourist typologies in his study. He classified the push and pull theory into two groups as anomic and individuals who want to raise their ego. He described the anomic tourists as desperate individuals bored with their routine lives, and defined the other group as tourists who want to raise their ego, see travel as a need rather than a purpose and want to realize themselves. Crompton (1979), on the other hand, revealed a total of 9 elements, including socio-psychological and cultural factors, in his study based on why individuals travel and push-pull factors. From a socio-psychological perspective, these stages are escape, self-discovery and evaluation, relaxation, prestige, regression, development of kinship relations and facilitation of social interaction (push factors). In a cultural sense, he stated them as innovation and education (pull factors).

\subsection{The Importance of Recreation in The Development of The Tourism Sector in Turkey}

As a result of the increasing demand for recreational activities, the demand for natural areas has also increased. Natural areas are preferred by many people for various touristic and recreational activities (Demir, 2002). Besides natural areas, recreational and touristic opportunities offered in artificial areas increase the choice of the destination. The basic features of the destination can provide effective and important benefits such as increasing the demand for tourism, offering various experiences to the tourists who prefer the destination, increasing the income opportunity, and strengthening the image of natural or artificial areas. The events organized by the destination also ensure that the area is preferred and recognized (Can, 2015).

The importance of tourism as a sector for the country's economies is increasing day by day (Öztürk and Şahbaz, 2017). As a result of the importance of economic benefits for the interests of the country, the importance of destinations has been understood by both local 
governments and governments. Turkey, in terms of destination image is one of the world's leading countries. It has important destinations with many touristic areas and recreational activities offered to tourists in touristic areas. Besides the natural beauty it has to offer in terms of tourism attraction areas of recreational activities as a result of the rich diversity of Turkey's tourism potential is very high. Preferring Fethiye Dead Sea for paragliding, choosing Uludağ or Palandöken for skiing, choosing Firtına Creek for rafting can be cited as an example of this situation. To sum up one of the important reasons for preferring the development of the tourism sector in Turkey and destinations that recreational activities are carried out in the destination. Since recreational activities are a concept that directly affects the tourism sector, they have contributed greatly to the formation of the destination image.

\section{Methodology}

In this study, the descriptive research approach was adopted, which is one of the quantitative research methods and is highly preferred in social sciences. The purpose of such studies is to investigate the current situation and determine the situation as a result of researches (Büyüköztürk et al., 2012). The universe of the research was composed of tourists who preferred the Orient Express travel. The sample of the study consisted of tourists traveling to Kars with the Orient Express between January and February. The sample group in the study was formed by choosing the individuals who preferred the Orient Express and Kars Destination between January and February based on the principle of voluntary participation by using the appropriate sampling method. A total of 432 individuals were reached in the study $(\mathrm{n}=432)$.

SPSS 21.0 program was used in the analysis of the data obtained in the study, the percentage and frequency descriptive statistical methods were employed to determine the distribution of the personal information of the participants, and the skewness and kurtosis values of the data were checked to determine whether the data showed normal distribution. As a result of the analyses made, it was determined that the data had a normal distribution. In the literature, the coefficients of skewness and kurtosis between -1 and +1 are considered sufficient for the normality assumption of the distribution (Field, 2009). In the statistical analysis of the data, besides descriptive statistics, t-test, ANOVA, Tukey HSD multiple comparison test, and correlation analysis methods were used for determining significant groups $(\alpha=0.05)$.

\section{Results}

\subsection{Descriptive Statistics}

As seen in Table 1, it was determined that regarding the participants within the scope of the study, $60.0 \%$ were male, $41.0 \%$ were in the $18-24$ age group, $64.6 \%$ were single, $48.8 \%$ had undergraduate education level, and $46.8 \%$ had an income level of 2,020 TL and below and $41.2 \%$ of them were students.

Table 1. Demographic information of the participants.

\begin{tabular}{|c|c|c|c|}
\hline \multicolumn{2}{|c|}{ Variables } & \multirow[b]{2}{*}{ frequency } & \multirow[b]{2}{*}{$\%$} \\
\hline & & & \\
\hline \multirow[t]{3}{*}{ Gender } & Female & 173 & 40.0 \\
\hline & Male & 259 & 60.0 \\
\hline & Total & 432 & 100 \\
\hline \multirow[t]{4}{*}{ Age } & $18-24$ years & 177 & 41.0 \\
\hline & $25-35$ years & 116 & 26.9 \\
\hline & $36-49$ years & 53 & 12.3 \\
\hline & 50 years and above & 86 & 19.9 \\
\hline
\end{tabular}




\begin{tabular}{|c|c|c|c|}
\hline & Total & 432 & 100 \\
\hline \multirow[t]{3}{*}{ Marital Status } & Married & 153 & 35.4 \\
\hline & Single & 279 & 64.6 \\
\hline & Total & 432 & 100 \\
\hline \multirow[t]{6}{*}{ Educational Status } & Primary School & 43 & 10.0 \\
\hline & High School & 83 & 19.2 \\
\hline & Associate Degree & 70 & 16.2 \\
\hline & Bachelor's Degree & 211 & 48.8 \\
\hline & Postgraduate & 25 & 5.8 \\
\hline & Total & 432 & 100 \\
\hline \multirow[t]{6}{*}{ Income level } & 2,020 TL and Below & 202 & 46.8 \\
\hline & $2,021-3,000 \mathrm{TL}$ & 71 & 16.4 \\
\hline & $3,001-4,000 \mathrm{TL}$ & 70 & 16.2 \\
\hline & $4,001-5,000 \mathrm{TL}$ & 26 & 6.0 \\
\hline & 5,001 and above & 63 & 14.6 \\
\hline & Total & 432 & 100 \\
\hline \multirow[t]{8}{*}{ Occupation } & Student & 178 & 41.2 \\
\hline & Public Employee & 60 & 13.9 \\
\hline & Private Sector Employee & 82 & $\overline{19.0}$ \\
\hline & Artisan-Merchant & 22 & 5.1 \\
\hline & Housewife & 28 & 6.5 \\
\hline & Retired & 46 & 10.6 \\
\hline & Other & 16 & 3.7 \\
\hline & Total & 432 & 100 \\
\hline
\end{tabular}

In the research, the "Recreational Activities in Destination Choice Scale" (RADCS), "Internal Travel Motivations Scale" (ITMS) and "External Travel Motivations Scale" (ETMS), the validity and reliability studies of which were carried out by Özdemir (2013), were used as data collection tools. In the rating scale (4-point Likert type) used to answer the statements in the scales, 1 is the lowest score, and 4 is the highest score ( $1=$ Absolutely Not Important, 2 = Not Important, 3 = Important, 4 = Absolutely Important) ( Özdemir, Büyüköztürk, and Karak Küçük, 2016) The recreational activities scale (RADCS) measures the importance ascribed to recreational activities and opportunities regarding Kars destination by individuals traveling to Kars with the Orient Express. The scale consists of 22 items. The Internal Travel Motivations Scale (ITMS) measures the importance of the reasons that push individuals to go on a vacation. The internal motivation scale consists of 40 items. The scale has five sub-dimensions. These sub-dimensions are experience-discovery, distancing, action, visiting and prestige. The external travel motivations scale measures how important the attributes of Kars destination are for individuals to prefer that destination. The scale consists of 40 items. The scale has five sub-dimensions. These are quality-atmosphere, cultural richness, natural richness, popularity and authentic-local environment. The study was carried out in January and February in 2020 after obtaining permission from the Republic of Turkey State Railways (TCDD) General Directorate with the principle of voluntary participation of the passengers traveling on the Orient Express. In the reliability analysis of this study, the Cronbach's alpha coefficient was found to be .71 for the Recreational Activities in Destination Choice Scale (RADCS),.63 for The Internal Travel Motivations Scale (ITMS), and .65 for the Extrinsic Travel Motivations Scale (ETMS). Also, the total reliability coefficient for the 3 scales was determined as .75 .

In Table 2, the participants' mean scores from the Recreational Activities in the Destination Choice Scale (RADCS), the Internal Travel Motivations Scale (ITMS) subdimensions and the External Travel Motivations Scale (ETMS) sub-dimensions are presented. Accordingly, it was determined that the highest mean score obtained from RADCS was 60.58 , 
that the highest mean score obtained from the sub-dimensions of ITMS was in the "Experience-Discovery (ITMS 1)" sub-dimension with 40.23, and that among ETMS subdimensions, the highest mean score was 38.89 in the "Quality-Atmosphere (ETMS 1)" subdimension. Besides, when the skewness and kurtosis values were controlled, it was found that the data were suitable for normal distribution.

Table 2. Distribution of scale scores (n 432).

\begin{tabular}{lcccrr}
\hline Sub-Dimensions & $\begin{array}{c}\text { Item } \\
\text { Number }\end{array}$ & Mean & SD & Skewness & Kurtosis \\
\hline $\begin{array}{l}\text { Recreational Activities in Destination } \\
\text { Choice Scale (RADCS) }\end{array}$ & 22 & 60.58 & 11.43 & -.060 & .732 \\
\hline Internal Travel Motivations Scale (ITMS) & 40 & 121.41 & 17.66 & -.092 & -.011 \\
\hline ITMS 1 (Experience-Discovery) & 12 & 40.23 & 5.92 & -.478 & -.438 \\
\hline ITMS 2 (Distancing) & 12 & 35.22 & 7.30 & -.272 & -.339 \\
\hline ITMS 3 (Action) & 6 & 16.50 & 4.48 & .586 & 4.87 \\
\hline ITMS 4 (Visiting) & 5 & 15.13 & 3.35 & -.476 & -.158 \\
\hline ITMS 5 (Prestige) & 5 & 14.31 & 3.69 & -.308 & -.494 \\
\hline External Travel Motivations Scale (ETMS) & 40 & 119.13 & 19.64 & .136 & .214 \\
\hline ETMS 1 (Quality-Atmosphere) & 12 & 38.89 & 6.25 & -.631 & .460 \\
\hline ETMS 2 (Cultural Richness) & 9 & 26.31 & 6.01 & -.217 & -.219 \\
\hline ETMS 3 (Natural Richness) & 7 & 20.07 & 4.75 & .028 & -.515 \\
\hline ETMS 4 (Popularity) & 7 & 18.06 & 5.66 & .119 & -.725 \\
\hline ETMS 5 (Authentic-Local Environment) & 5 & 15.78 & 3.27 & -.607 & .348 \\
\hline
\end{tabular}

In the current study, the importance given to recreational activities, internal and external travel motivations by individuals traveling to Kars with the Orient Express was evaluated in terms of various variables such as gender, age, marital status, income level, and occupation. The tets results were presented in tables from 3 to 9 respectively. Table 3 presents the t-test results by gender.

Table 3. T-Test table for the distribution of the recreational activities in destination choice scale (radcs), the internal travel motivations scale (itms) sub-dimensions and the subdimensions of the external travel motivations scale (etms) by gender variable.

\begin{tabular}{|c|c|c|c|c|c|}
\hline Sub-Dimensions & Variable & Mean & SD & $\mathbf{t}$ & $\mathbf{p}$ \\
\hline \multirow{2}{*}{$\begin{array}{l}\text { Recreational Activities in Destination Choice } \\
\text { Scale }\end{array}$} & Female & 60.2775 & 10.76619 & \multirow[t]{2}{*}{-.454} & \multirow[t]{2}{*}{.650} \\
\hline & Male & 60.7876 & 11.87619 & & \\
\hline \multirow[t]{2}{*}{ ITMS 1 (Experience-Discovery) } & Female & 41.3121 & 5.27342 & \multirow[t]{2}{*}{3.131} & \multirow[t]{2}{*}{.002} \\
\hline & Male & 39.5097 & 6.22658 & & \\
\hline \multirow[t]{2}{*}{ ITMS 2 (Distancing) } & Female & 36.0000 & 6.43754 & \multirow[t]{2}{*}{1.807} & \multirow[t]{2}{*}{.071} \\
\hline & Male & 34.7066 & 7.80670 & & \\
\hline \multirow[t]{2}{*}{ ITMS 3 (Action) } & Female & 16.4220 & 4.58397 & \multirow[t]{2}{*}{-.304} & \multirow[t]{2}{*}{.761} \\
\hline & Male & 16.5560 & 4.43294 & & \\
\hline \multirow[t]{2}{*}{ ITMS 4 (Visiting) } & Female & 15.1618 & 3.28799 & \multirow[t]{2}{*}{.139} & \multirow[t]{2}{*}{.889} \\
\hline & Male & 15.1158 & 3.41141 & & \\
\hline \multirow[t]{2}{*}{ ITMS 5 (Prestige) } & Female & 14.3064 & 3.45634 & \multirow[t]{2}{*}{-.060} & \multirow[t]{2}{*}{.952} \\
\hline & Male & 14.3282 & 3.85448 & & \\
\hline \multirow[t]{2}{*}{ ETMS 1 (Quality-Atmosphere) } & Female & 39.7457 & 5.23562 & \multirow[t]{2}{*}{2.332} & \multirow[t]{2}{*}{.020} \\
\hline & Male & 38.3205 & 6.80470 & & \\
\hline
\end{tabular}




\begin{tabular}{|c|c|c|c|c|c|}
\hline \multirow{2}{*}{ ETMS 2 (Cultural Richness) } & Female & 26.3699 & 5.30704 & \multirow{2}{*}{.156} & \multirow{2}{*}{.876} \\
\hline & Male & 26.2780 & 6.45196 & & \\
\hline \multirow[t]{2}{*}{ ETMS 3 (Natural Richness) } & Female & 19.5838 & 4.62050 & \multirow[t]{2}{*}{-1.771} & \multirow[t]{2}{*}{.077} \\
\hline & Male & 20.4093 & 4.82910 & & \\
\hline \multirow[t]{2}{*}{ ETMS 4 (Popularity) } & Female & 18.0983 & 5.31307 & \multirow[t]{2}{*}{.086} & \multirow[t]{2}{*}{.931} \\
\hline & Male & 18.0502 & 5.90045 & & \\
\hline \multirow[t]{2}{*}{ ETMS 5 (Authentic-Local Environment) } & Female & 15.7283 & 3.11619 & \multirow[t]{2}{*}{-.268} & \multirow[t]{2}{*}{.789} \\
\hline & Male & 15.8147 & 3.37978 & & \\
\hline
\end{tabular}

Table 4 presents the results of the t-Test performed on RADCS and the sub-dimensions of ITMS and ETMS in terms of gender variable, it was determined that there was a significant difference in ITMS "Experience-Discovery" sub-dimension ( $\mathrm{p}<0.05)$ and ETMS "QualityAtmosphere" sub-dimension, and that there were no differences in terms of other subdimensions ( $\mathrm{p}>0.05)$.

Table 4. ANOVA test results for the distribution of the recreational activities in destination choice scale (radcs), the internal travel motivations scale (itms) sub-dimensions and the subdimensions of the external travel motivations scale (etms) by age variable.

\begin{tabular}{|c|c|c|c|c|c|}
\hline Sub-Dimensions & Variable & Mean & SD & $\mathbf{F}$ & p \\
\hline \multirow[t]{4}{*}{ ITMS 1 (Experience-Discovery) } & $18-24$ years & 41.0508 & 5.53118 & \multirow[t]{4}{*}{2.979} & \multirow[t]{4}{*}{.031} \\
\hline & $25-35$ years & 40.2931 & 6.32045 & & \\
\hline & $36-49$ years & 39.6604 & 5.99661 & & \\
\hline & $\begin{array}{c}50 \text { years and } \\
\text { Above }\end{array}$ & 38.8140 & 5.90615 & & \\
\hline \multirow[t]{4}{*}{ ITMS 2 (Distancing) } & $18-24$ years & 36.7062 & 7.07537 & \multirow[t]{4}{*}{5.617} & \multirow[t]{4}{*}{.001} \\
\hline & $25-35$ years & 35.1466 & 7.48593 & & \\
\hline & $36-49$ years & 33.9057 & 6.84236 & & \\
\hline & $\begin{array}{c}50 \text { years and } \\
\text { Above }\end{array}$ & 33.0930 & 7,24630 & & \\
\hline \multirow[t]{4}{*}{ ITMS 4 (Visiting) } & $18-24$ years & 14.6723 & 3.36847 & \multirow[t]{4}{*}{2.869} & \multirow[t]{4}{*}{.036} \\
\hline & $25-35$ years & 15.0776 & 3.33662 & & \\
\hline & $36-49$ years & 15.9057 & 3.19413 & & \\
\hline & $\begin{array}{l}50 \text { years and } \\
\text { Above }\end{array}$ & 15.6860 & 3.35809 & & \\
\hline \multirow[t]{4}{*}{ ETMS 1 (Quality-Atmosphere) } & $18-24$ years & 38.4124 & 6.31777 & \multirow[t]{4}{*}{3.303} & \multirow[t]{4}{*}{.020} \\
\hline & $25-35$ years & 38.2931 & 6.82453 & & \\
\hline & $36-49$ years & 38.7736 & 5.74001 & & \\
\hline & $\begin{array}{c}50 \text { years and } \\
\text { Above }\end{array}$ & 40.7558 & 5.30912 & & \\
\hline \multirow[t]{4}{*}{ ETMS 4 (Popularity) } & $18-24$ years & 18.2655 & 5.67216 & \multirow[t]{4}{*}{2.985} & \multirow[t]{4}{*}{.031} \\
\hline & $25-35$ years & 17.0086 & 6.04547 & & \\
\hline & $36-49$ years & 17.6792 & 5.00297 & & \\
\hline & $\begin{array}{c}50 \text { years and } \\
\text { Above }\end{array}$ & 19.3372 & 5.29952 & & \\
\hline
\end{tabular}

Table 5 presents the results of the ANOVA test conducted on the sub-dimensions of the Recreational Activities in Destination Choice Scale and Internal Travel Motivations (ITMS) and the External Travel Motivations Scale (ETMS) according to the age variable, it was determined that there was a significant difference in terms of ITMS 1 (ExperienceExploration), ITMS 2 (Distancing), ITMS 4 (Visiting), ETMS 1 (Quality-Atmosphere) and ETMS 4 (Popularity) sub-dimensions by the age variable $(\mathrm{p}<0.05)$. According to the Tukey HSD multiple comparison test and the mean values performed in the sub-dimensions where 
there was a significant difference, it was determined that the significant difference was caused by the participants who were "18-24" and "50 years and above" old.

Table 5. T-test table for the distribution of the recreational activities in destination choice scale (radcs), the internal travel motivations scale (itms) sub-dimensions and the subdimensions of the external travel motivations scale (etms) by marital status variable.

\begin{tabular}{|c|c|c|c|c|c|}
\hline Sub-Dimensions & Variable & Mean & SD & $\mathbf{t}$ & $\mathbf{p}$ \\
\hline \multirow{2}{*}{$\begin{array}{l}\text { Recreational Activities in } \\
\text { Destination Choice Scale }\end{array}$} & Married & 60.2484 & 12.13807 & \multirow[t]{2}{*}{-.450} & \multirow[t]{2}{*}{.653} \\
\hline & Single & 60.7670 & 11.04794 & & \\
\hline \multirow{2}{*}{$\begin{array}{l}\text { ITMS } 1 \text { (Experience- } \\
\text { Discovery) }\end{array}$} & Married & 38.9542 & 6.07664 & \multirow[t]{2}{*}{-3.358} & \multirow[t]{2}{*}{001} \\
\hline & Single & 40.9319 & 5.72879 & & \\
\hline \multirow[t]{2}{*}{ ITMS 2 (Distancing) } & Married & 33.1569 & 7.41364 & \multirow[t]{2}{*}{-4.448} & \multirow[t]{2}{*}{.000} \\
\hline & Single & 36.3584 & 7.00928 & & \\
\hline \multirow[t]{2}{*}{ ITMS 3 (Action) } & Married & 16.7059 & 4.82848 & \multirow[t]{2}{*}{.698} & \multirow[t]{2}{*}{.486} \\
\hline & Single & 16.3907 & 4.29673 & & \\
\hline \multirow[t]{2}{*}{ ITMS 4 (Visiting) } & Married & 15.6275 & 3.28650 & \multirow[t]{2}{*}{2.271} & \multirow[t]{2}{*}{.024} \\
\hline & Single & 14.8638 & 3.37299 & & \\
\hline \multirow[t]{2}{*}{ ITMS 5 (Prestige) } & Married & 13.9150 & 3.67414 & \multirow[t]{2}{*}{-1.688} & \multirow[t]{2}{*}{.092} \\
\hline & Single & 14.5412 & 3.69584 & & \\
\hline \multirow{2}{*}{$\begin{array}{l}\text { ETMS } 1 \text { (Quality- } \\
\text { Atmosphere) }\end{array}$} & Married & 39.7712 & 6.00164 & \multirow[t]{2}{*}{2.174} & \multirow[t]{2}{*}{.030} \\
\hline & Single & 38.4086 & 6.35107 & & \\
\hline \multirow[t]{2}{*}{ ETMS 2 (Cultural Richness) } & Married & 26.1307 & 5.69590 & \multirow[t]{2}{*}{-.471} & \multirow[t]{2}{*}{.638} \\
\hline & Single & 26.4158 & 6.18823 & & \\
\hline \multirow[t]{2}{*}{ ETMS 3 (Natural Richness) } & Married & 19.7124 & 4.48194 & \multirow[t]{2}{*}{-1.185} & \multirow[t]{2}{*}{.237} \\
\hline & Single & 20.2796 & 4.89978 & & \\
\hline \multirow[t]{2}{*}{ ETMS 4 (Popularity) } & Married & 18.3922 & 5.40983 & \multirow[t]{2}{*}{.876} & \multirow[t]{2}{*}{.381} \\
\hline & Single & 17.8925 & 5.80398 & & \\
\hline \multirow{2}{*}{$\begin{array}{l}\text { ETMS } 5 \text { (Authentic-Local } \\
\text { Environment) }\end{array}$} & Married & 15.7712 & 3.00985 & \multirow[t]{2}{*}{-.042} & \multirow[t]{2}{*}{.967} \\
\hline & Single & 15.7849 & 3.41447 & & \\
\hline
\end{tabular}

Table 6 presents the results of the t-Test conducted between the sub-dimensions of the RADCS, ITMS and ETMS according to the marital status variable, it was determined that there was a significant difference between the ITMS "Experience-Discovery", "Distancing" and "Visiting" sub-dimensions and the ETMS "Quality-Atmosphere" sub-dimensions ( $\mathrm{p}<$ 0.05), and that there was no significant difference in the other sub-dimensions and Recreational Activities in Destination Choices Scale $(\mathrm{p}>0.05)$.

Table 6. Anova test results for the distribution of the recreational activities in destination choice scale (radcs), the internal travel motivations scale (itms) sub-dimensions and the subdimensions of the external travel motivations scale (etms) by educational status variable.

\begin{tabular}{lccccc}
\hline Sub-Dimensions & Variable & Mean & SD & F & p \\
\hline ITMS 1 (Experience-Discovery) & 18-24 years & 41.0508 & 5.53118 & 2.979 & $\mathbf{. 0 3 1}$ \\
& 25-35 years & 40.2931 & 6.32045 & & \\
\cline { 2 - 4 } & 36-49 years & 39.6604 & 5.99661 \\
& $\begin{array}{c}\text { 50 years and } \\
\text { Above }\end{array}$ & 38.8140 & 5.90615 & \\
& & & & \\
\hline ITMS 2 (Distancing) & 18-24 years & 36.7062 & 7.07537 & 5.617 & $\mathbf{. 0 0 1}$
\end{tabular}




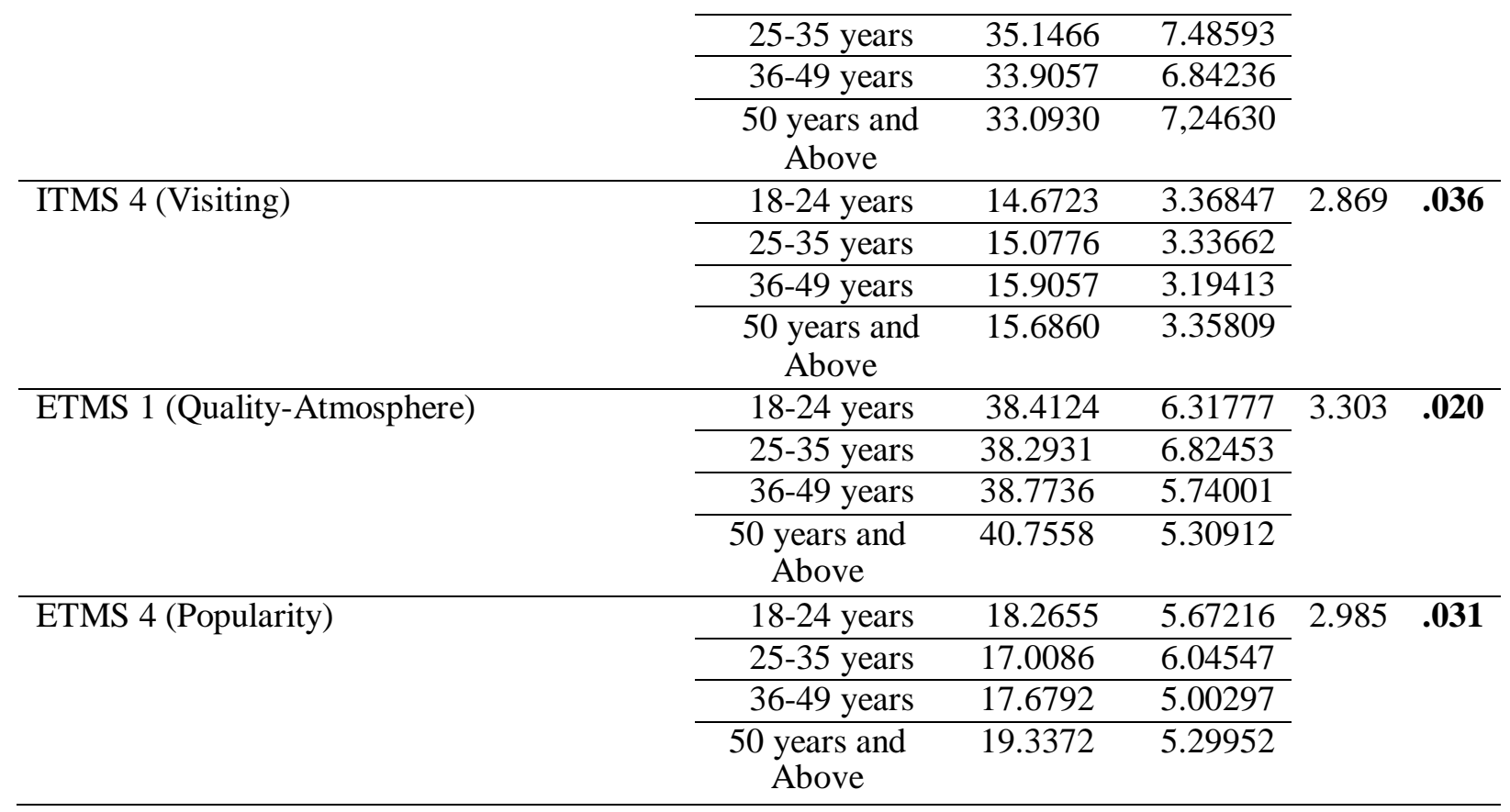

Table 7 presents the results of the ANOVA Test conducted between the sub-dimensions of the Recreational Activities in Destination Choice Scale and Internal Travel Motivations (ITMS) and the External Travel Motivations Scale (ETMS) according to the educational status variable, a significant difference was determined in ITMS 3 (Action), ITMS 4 (Visiting), ITMS 5 (Prestige) and ETMS 4 (Popularity) sub-dimensions according to the educational level variable $(\mathrm{p}<0.05)$.

Table 7. Anova test results for the distribution of the recreational activities in destination choice scale (radcs), the internal travel motivations scale (itms) sub-dimensions and the subdimensions of the external travel motivations scale (etms) by income level variable.

\begin{tabular}{|c|c|c|c|c|c|}
\hline Sub-Dimensions & Variable & Mean & SD & $\mathbf{F}$ & $\mathbf{p}$ \\
\hline \multirow[t]{5}{*}{ ITMS 2 (Distancing) } & $\begin{array}{l}2,020 \mathrm{TL} \text { and } \\
\text { Below }\end{array}$ & 36.6535 & 6.62565 & 4.382 & .002 \\
\hline & $2,021-3,000$ & 34.8873 & 7.90940 & & \\
\hline & $3,001-4,000$ & 33.8143 & 7.56478 & & \\
\hline & $4,001-5,000$ & 34.3846 & 8.07998 & & \\
\hline & 5,001 and Above & 32.9365 & 7.33281 & & \\
\hline \multirow[t]{5}{*}{ ITMS 5 (Prestige) } & $\begin{array}{c}2,020 \mathrm{TL} \text { and } \\
\text { Below }\end{array}$ & 14.9505 & 3.45512 & 3.584 & .007 \\
\hline & $2,021-3,000$ & 14.0845 & 4.06289 & & \\
\hline & $3,001-4,000$ & 14.0857 & 3.62257 & & \\
\hline & $4,001-5,000$ & 13.5385 & 3.32543 & & \\
\hline & 5,001 and Above & 13.1429 & 3.93437 & & \\
\hline
\end{tabular}

Table 8 presents the results of the ANOVA Test conducted between the sub-dimensions of the Recreational Activities in Destination Choice Scale and Internal Travel Motivations (ISMÖ) and the External Travel Motivations Scale (WHMO) according to the income level variable, a significant difference was determined in the sub-dimensions of ITMS 2 (Distancing) and ITMS 5 (Prestige) $(\mathrm{p}<0.05)$. According to the Tukey HSD multiple comparison test and the mean values performed in the sub-dimensions where there was a significant difference, it was determined that the significant difference was caused by the participants with an income level of "2,020 TL and below" and "5,001 TL and above." 
Table 8. Anova test results for the distribution of the recreational activities in destination choice scale (radcs), the internal travel motivations scale (itms) sub-dimensions and the subdimensions of the external travel motivations scale (etms) by occupation variable.

\begin{tabular}{|c|c|c|c|c|c|}
\hline Sub-Dimensions & Variable & Mean & SD & $\mathbf{F}$ & $\mathbf{p}$ \\
\hline \multirow[t]{7}{*}{ ITMS 2 (Distancing) } & Student & 37.0506 & 6.62155 & \multirow{7}{*}{3.950} & \multirow[t]{7}{*}{.001} \\
\hline & Public Employee & 32.7500 & 7.77354 & & \\
\hline & $\begin{array}{l}\text { Private Sector } \\
\text { Employee }\end{array}$ & 34.7805 & 7.56213 & & \\
\hline & Artisan-Merchant & 35.1818 & 9.50006 & & \\
\hline & Housewife & 33.7500 & 6.07134 & & \\
\hline & Retired & 33.2826 & 7.25309 & & \\
\hline & Other & 34.6875 & 6.28987 & & \\
\hline \multirow[t]{7}{*}{ ITMS 4 (Visiting) } & Student & 14.6629 & 3.39805 & \multirow[t]{7}{*}{2.955} & \multirow[t]{7}{*}{.008} \\
\hline & Public Employee & 15.8833 & 2.69395 & & \\
\hline & $\begin{array}{l}\text { Private Sector } \\
\text { Employee }\end{array}$ & 15.2073 & 3.40927 & & \\
\hline & Artisan-Merchant & 14.3636 & 4.70608 & & \\
\hline & Housewife & 16.6071 & 2.65747 & & \\
\hline & Retired & 15.7826 & 3.01782 & & \\
\hline & Other & 13.8125 & 3.54436 & & \\
\hline \multirow[t]{7}{*}{ ITMS 5 (Prestige) } & Student & 14.7135 & 3.72379 & \multirow[t]{7}{*}{2.252} & \multirow[t]{7}{*}{.038} \\
\hline & Public Employee & 13.2167 & 3.99615 & & \\
\hline & $\begin{array}{l}\text { Private Sector } \\
\text { Employee }\end{array}$ & 14.5488 & 3.42162 & & \\
\hline & Artisan-Merchant & 14.8182 & 4.42543 & & \\
\hline & Housewife & 14.6786 & 3.38902 & & \\
\hline & Retired & 14.0652 & 3.36916 & & \\
\hline & Other & 12.3125 & 2.93754 & & \\
\hline \multirow[t]{7}{*}{ ETMS 4 (Popularity) } & Student & 17.9101 & 5.81764 & \multirow{7}{*}{2.163} & \multirow{7}{*}{.046} \\
\hline & Public Employee & 17.3333 & 5.03098 & & \\
\hline & $\begin{array}{l}\text { Private Sector } \\
\text { Employee }\end{array}$ & 17.7561 & 5.83849 & & \\
\hline & Artisan-Merchant & 20.0455 & 5.90784 & & \\
\hline & Housewife & 18.1429 & 5.28950 & & \\
\hline & Retired & 20.0652 & 5.16571 & & \\
\hline & Other & 15.6250 & 5.73730 & & \\
\hline
\end{tabular}

Table 9 presents the results of the ANOVA Test conducted between the sub-dimensions of the Recreational Activities in Destination Choice Scale and Internal Travel Motivations (ITMS) and the External Travel Motivations Scale (ETMS) according to the occupation variable, a significant difference was identified in ITMS 2 (Distancing), ITMS 4 (Visiting) and ITMS 5 (Prestige) and ETMS 4 (Popularity) sub-dimensions according to the occupation of the participants $(\mathrm{p}<0.05)$.

Table 9. Correlation analysis table for the relationship between the recreational activities in destination choice scale (radcs), the internal travel motivations scale (itms) and the external travel motivations scale (etms).

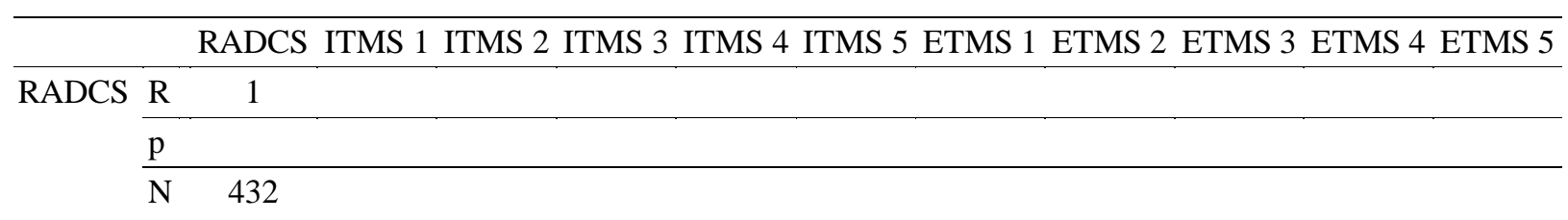




\begin{tabular}{|c|c|c|c|c|c|c|c|c|c|c|c|c|}
\hline \multirow[t]{3}{*}{ ITMS 1} & $\mathrm{R}$ & $.317^{* * *}$ & 1 & & & & & & & & & \\
\hline & $\mathrm{p}$ & .000 & & & & & & & & & & \\
\hline & $\mathrm{N}$ & 432 & 432 & & & & & & & & & \\
\hline \multirow[t]{3}{*}{ ITMS 2} & $\mathrm{R}$ & $.344^{* *}$ & $.405^{* *}$ & 1 & & & & & & & & \\
\hline & $\mathrm{p}$ & .000 & .000 & & & & & & & & & \\
\hline & $\mathrm{N}$ & 432 & 432 & 432 & & & & & & & & \\
\hline \multirow[t]{3}{*}{ ITMS 3} & $\mathrm{R}$ & $.517^{* * *}$ & $.336^{* *}$ & $.341^{* *}$ & 1 & & & & & & & \\
\hline & $\mathrm{p}$ & .000 & .000 & .000 & & & & & & & & \\
\hline & $\mathrm{N}$ & 432 & 432 & 432 & 432 & & & & & & & \\
\hline \multirow[t]{3}{*}{ ITMS 4} & $\mathrm{R}$ & $.338^{* *}$ & $.265^{* *}$ & $.201^{* *}$ & $.560^{* *}$ & 1 & & & & & & \\
\hline & $\mathrm{p}$ & .000 & .000 & .000 & .000 & & & & & & & \\
\hline & $\mathrm{N}$ & 432 & 432 & 432 & 432 & 432 & & & & & & \\
\hline \multirow[t]{3}{*}{ ITMS 5} & $\mathrm{R}$ & $.377^{* * *}$ & $.336^{* *}$ & $.501^{* *}$ & $.421^{* * *}$ & $.411^{* *}$ & 1 & & & & & \\
\hline & $\mathrm{p}$ & .000 & .000 & .000 & .000 & .000 & & & & & & \\
\hline & $\mathrm{N}$ & 432 & 432 & 432 & 432 & 432 & 432 & & & & & \\
\hline \multirow[t]{3}{*}{$\overline{\text { ETMS } 1}$} & $\mathrm{R}$ & $.347^{* *}$ & $.240^{* *}$ & $.281^{* *}$ & $.323^{* *}$ & $.276^{\text {*** }}$ & $.282^{* *}$ & 1 & & & & \\
\hline & $\mathrm{p}$ & .000 & .000 & .000 & .000 & .000 & .000 & & & & & \\
\hline & $\mathrm{N}$ & 432 & 432 & 432 & 432 & 432 & 432 & 432 & & & & \\
\hline \multirow[t]{3}{*}{$\overline{\text { ETMS } 2}$} & $\mathrm{R}$ & $.497^{* *}$ & $.286^{* *}$ & $.328^{* *}$ & $.412^{* *}$ & $.304^{* *}$ & $.311^{* *}$ & $.497^{* *}$ & 1 & & & \\
\hline & $\mathrm{p}$ & .000 & .000 & .000 & .000 & .000 & .000 & .000 & & & & \\
\hline & $\mathrm{N}$ & 432 & 432 & 432 & 432 & 432 & 432 & 432 & 432 & & & \\
\hline \multirow[t]{3}{*}{ ETMS 3} & $\mathrm{R}$ & $.396^{* *}$ & $.244^{* *}$ & $.299^{* *}$ & $.284^{* *}$ & $.154^{* * *}$ & $.205^{* *}$ & $.312^{* *}$ & $.593^{* *}$ & 1 & & \\
\hline & $\mathrm{p}$ & .000 & .000 & .000 & .000 & .001 & .000 & .000 & .000 & & & \\
\hline & $\mathrm{N}$ & 432 & 432 & 432 & 432 & 432 & 432 & 432 & 432 & 432 & 432 & \\
\hline \multirow[t]{3}{*}{ ETMS 4} & $\mathrm{R}$ & $.377^{* *}$ & $.173^{* *}$ & $.300^{* *}$ & $.349^{* * *}$ & $.307^{* *}$ & $.499^{* *}$ & $.491^{* *}$ & $.504^{* *}$ & $.329^{* *}$ & 1 & \\
\hline & $\mathrm{p}$ & .000 & .000 & .000 & .000 & .000 & .000 & .000 & .000 & .000 & & \\
\hline & $\mathrm{N}$ & 432 & 432 & 432 & 432 & 432 & 432 & 432 & 432 & 432 & 432 & \\
\hline \multirow[t]{3}{*}{ ETMS 5} & $\mathrm{R}$ & $.369^{* *}$ & $.322^{* *}$ & $.384^{* *}$ & $.289^{* *}$ & $.290^{* * *}$ & $.323^{* *}$ & $.496^{* *}$ & $.482^{* *}$ & $.358^{* *}$ & $.484^{* *}$ & 1 \\
\hline & $\mathrm{p}$ & .000 & .000 & .000 & .000 & .000 & .000 & .000 & .000 & .000 & .000 & \\
\hline & $\mathrm{N}$ & 432 & 432 & 432 & 432 & 432 & 432 & 432 & 432 & 432 & 432 & 432 \\
\hline
\end{tabular}

As a result of the correlation analysis, the correlation between RADCS, ITMS and ETMS scales was found to be positively significant. It was concluded that recreational activities in destination choice and internal and external travel motivations were in a relationship positively influencing each other. Similar results were found in the study conducted by Özdemir et al. (2016).

\section{Conclusions, Implications and Limitations}

Since the recreational activities in destination choice scale have been used in a limited number of studies both Turkey and the world, the available data close the findings obtained from Recreational Activities in Destination Choice Scale were included in the study. Besides, due to the limited number of studies in which all the sub-dimensions of the Internal and External Travel Motivation Scales are equivalent, dimensions that are suitable for and in parallel with the sub-dimensions of these scales were included in the study and were sampled in a way that could be appropriate for various variables.

There was no significant difference between the gender of individuals traveling to Kars with the Orient Express and the importance they attached to recreational activities in their 
destination choice $(\mathrm{p}<00.5)$. The results of the study conducted by Akyürek and Köroğlu (2017) support these results. In the study conducted by Toprak, Serçek and Özaltaş Serçek (2014) on university students, findings in the opposite direction of the study were found, and it was revealed that male participants attached more importance to leisure activities than female participants.

A significant difference was found between the gender variable and the "ExperienceDiscovery" sub-dimension of the internal travel motivation scale, and it was revealed that female participants attached more importance to the "Experience-Discovery" sub-dimension than male participants $(\mathrm{p}<0.05)$. According to a study conducted by Kervankıran and İlban (2019), it was stated that the three most important factors that motivate women to travel were the idea of being free, exploring new places and getting to know different cultures. This result coincides with the findings of the research. In the study conducted by Karadaşl1 (2019), no significant difference was found between the individual's motivation for travel and the gender variable.

A significant difference was found between the "Quality-Atmosphere" sub-dimension of the external travel motivations scale and the gender variable, and it was determined that female participants attributed more importance to the "Quality-Atmosphere" sub-dimension than male participants $(\mathrm{p}<0.05)$. Besides, it was found that female participants attached more importance to the "Cultural Richness" and "Popularity" sub-dimensions than male participants. In a study conducted by Andreu et al. (2006), it was revealed that travel motivations differed according to gender, and that female participants had higher mean scores than male participants. In a study by Aziz et al. (2018), no significant difference was found between travel motivation and the individuals' gender variable.

There was no significant difference between the age of individuals traveling to Kars with the Orient Express and the importance they attached to recreational activities in their destination choice ( $\mathrm{p}<00.5)$. According to a study conducted by Gümüş (2012), no difference was found between the location choices and age of the individuals who came to parks and recreation areas for physical activity. This result may be evaluated as supporting the findings of the research. According to a study conducted by Başarangil, Alyunel, and Tokatl1 (2016), it was revealed that recreational activities in destination choice differed according to the age variable of individuals. This result can be evaluated in the opposite direction of the research findings.

A significant difference was found between the "Experience-Discovery" sub-dimension, the "Distancing" sub-dimension and the "Visiting" sub-dimension of the internal travel motivations scale and age variables $(\mathrm{p}<0.05)$. It was determined that the age group that attached the most importance to the "Experience-Discovery" and "Distancing" subdimensions was the age group between the ages of 18-24. It was determined that the group attaching the most importance to the "visiting" sub-dimension was individuals aged 50 and over. These differences are thought to have stemmed from the fact that most of the individuals between the ages of 18-24 had undergraduate education, and that they aimed to get away from their monotonous lives due to school life and the stresses of daily life and to be able to see new places.

It was determined that there was a significant difference between the "QualityAtmosphere" and "Popularity" sub-dimensions of the external travel motivations scale and the age variable $(\mathrm{p}<00.5)$. It was revealed that individuals aged 50 and over-attached more importance to the "Quality-Atmosphere" and "Popularity" sub-dimensions than other age groups. It is thought that the importance attached to the attributes and phenomenon of the destination by individuals aged 50 and over may be due to the comfort and quality of the travel process. Besides, this difference is thought to have stemmed from the fact that individuals of this age group may have paid more attention to basic features such as the comfort of the journey, services offered by the destination, and security compared to young 
participants. In the study conducted by Jang and Wu (2006), it was revealed that the subdimension that tourists attached the most importance to in their external travel motivation was "Cleanliness and Safety." In the study conducted by Pattanapokinsakul and Phakdee-auksorn (2013) to determine the travel motivation of tourists, no significant difference was found between the age groups of individuals and the dimensions of "Safety", "Quality" and "Good Weather", which are factors of external travel motivation.

It was revealed that there was no significant difference between the recreational activities in destination choice scale and the marital status of the participants $(\mathrm{p}<0.05)$. According to a study conducted by Gümüş, Alay, and Karakılıç (2017), no significant difference was found between the individuals who came to various physical activity-based parks and areas and the marital status variable. According to the findings of the study conducted by Armutçu (2018), differences in the marital status variable were determined.

Significant differences were found between the "Experience-Discovery", "Distancing" and "Visiting" sub-dimensions of the internal travel motivation scale and the marital status variables of the individuals ( $\mathrm{p}<0.05$ ). It was determined that single participants attached more importance to the sub-dimensions "Distancing" and "Visiting" than married participants. Similar results were obtained in the study conducted by $\mathrm{Li}$, Wen and Leung, (2011). According to the study conducted by Ferreira, Perks, and Oosthuizen (2015), it was found that there was a significant difference between the travel motivation of the participants and the marital status variable.

In the sub-dimensions of external travel motivation, the "Popularity" sub-dimension was found to differ according to marital status ( $p$ <.05). It was found that married participants attached more importance to the "Popularity" sub-dimension than single participants. In the study conducted by Woyo, Slabbert, and Saayman (2019) on tourists visiting Zimbabwe, no significant difference was found between the pull factors and the marital status of the participants. In a study conducted by Mohsin (2008) on Chinese tourists visiting New Zealand, significant differences were found between the sub-dimensions of travel motivation that affect tourists' preference for New Zealand and the marital status of the participants. It was determined that single individuals had higher scores than married individuals in terms of visiting different places and visiting various temples and beaches.

According to the Tukey HSD multiple comparison test and the mean values of the subdimensions where there was a significant difference, it was determined that the significant difference was determined to have been caused by the participants with "Primary School Education", and "Undergraduate" and "Postgraduate" degrees. In the study conducted by Tangeland Aas and Odden (2013), differences were found between individuals' educational status and their preference for outdoor recreation activities. It was found that individuals with postgraduate education level had more opportunities to participate in adventure activities and recreational activities such as trekking and hunting in mountainous areas compared to other groups with different educational levels. In the study titled "The Effect of Socio-Economic Structure on Recreational Tendencies and Demands: The Case of Bartın City" by Talay, Kaya and Belkayalı (2010), it was revealed that the recreational activities preferred by individuals differed according to their education level.

A significant difference was found between the internal travel motivation and the education level of the individuals $(\mathrm{p}<0.05)$. Significant differences were determined between the "Action", "Visiting" and " Prestige" sub-dimensions of the intrinsic travel motivation scale and the variable of the education level of the individuals, and it was revealed that the "Action" dimension was attached more importance by individuals with primary school education, that the "Visiting" dimension was attached the most importance by the individuals with postgraduate education level, and that the "Prestige" dimension was emphasized by individuals with the Associate Degree education variable. A significant difference was found between the variables of external travel motivation and the educational status of the 
participants $(\mathrm{p}<0.05)$. While it was determined that the "Popularity" sub-dimension of the external travel motivation scale showed a significant difference according to the education variable, it was found that the group that gave the most importance to this sub-dimension was composed of the participants with the primary school education variable.

In a doctoral dissertation by Alghamdi (2007) on Saudi tourists traveling to France, Bahrain and Egypt, significant differences were determined between the educational status of the participants and their internal and external travel motivations. It was revealed that among the groups that attached the most importance to the "Social-Sports " dimension were the individuals with primary school education who traveled to Bahrain, and the education group that attached the most importance to the "Making Use of Natural Resources" sub-dimension was the individuals traveling to Bahrain with a postgraduate education level. Besides, the education variable group that attached the most importance to the dimension of "Prestige" was the secondary school education group traveling to Bahrain and Egypt, and among the participants traveling to France, the education group that placed the highest importance on the "'Prestige" sub-dimension was determined to be the primary school education group. In the study conducted by Seyanont (2017) to determine the travel motivation of European elderly tourists visiting Thailand, no significant difference was found between individuals' educational status and their internal and external travel motivations.

No significant difference was found between the recreational activities in destination choice scale and income level ( $p>0.05$ ). According to the income level, it is seen that the group that attached the most importance to destination-oriented recreational activities consisted of individuals who earned between 2,001-3,000 TL. According to the article by Ersoy and Güldemir (2008), a significant difference was found between the income variable of individuals and the "travel-vacation" sub-dimension of the scale of engaging in leisure activities. It was determined that the participants with higher income (pocket money) showed more interest in the "travel-vacation" sub-dimension than the participants with less money. In the study conducted by Kaya (2007), differences were found between the choice of and participation in recreational activities and the income levels of individuals. In a study conducted by Türker, Ölçer, and Aydın (2016), no significant difference was found between the individuals' thoughts about leisure time activities and the income level variable.

A significant difference was found between the sub-dimensions of the internal travel motivation scale and the income variable of individuals $(p<0.05)$. It was revealed that the income group that attached the most importance to the sub-dimensions of "Distancing" and "Prestige", which are the sub-dimensions of internal travel motivations, was the group with an income level of "2,020 TL and below." It was determined that the income group that attached the least importance to the sub-dimensions of "Distancing" and "Prestige" was the individuals with "5,001 TL and above" income level. There was no significant difference between the sub-dimensions of the external travel motivations scale and the income variable $(p>0.05)$. In the study conducted by Jensen (2011), significant differences were found between participants' travel motivations and income level variables. While a significant difference was detected between the "Escape-Relaxation", "Natural Beauties" dimensions, which are the subdimensions of travel motivation, and income level variables, no significant difference was found in the "Prestige" dimension. It was revealed that the income level group which attached the greatest importance to the prestige dimension consisted of individuals with the lowest income level, while the group that valued the prestige dimension the least was composed of individuals with the highest income level. In the study conducted by Zhang (2009), significant differences were found between internal and external travel motivations and income group variables. Significant differences were determined between the "Information Search" and "Relaxation" sub-dimensions, which are among the internal travel motivations, and the income level variable. In the "Entertainment and Activities", "Facilities", "Weather Condition" and "Value of Money" sub-dimensions of external travel motivation, significant 
differences were revealed according to the income levels of the participants. Hanqin and Lam (1999) found that the importance ascribed to the "Prestige" dimension increased according to the income level, but it was stated that this situation was not observed in individuals with the highest income level. In a study conducted by Kasim et al. (2013), no significant difference was found between the travel motivation of domestic tourists and income level variables.

No significant difference was found between the recreational activities in destination choice scale and the occupation variable of the participants $(p>0.05)$. It was revealed that the occupational group that attached the most importance to the scale of recreational activities in the destination choice consisted of students and retired individuals. In the study conducted by Öztürk and Tecimen (2017) to determine the leisure time habits of the people of Çankır1, significant differences were found between the time spent by the participants for leisure activities and their occupations, and it was found that students, retired participants and housewives allocated more time for leisure activities. In the study conducted by Türker et al. (2016) on determining the leisure time habits of Safranbolu people, no significant difference was found between the occupational variable of the participants and their participation in leisure time activities.

Significant differences were found between the participants' occupational variables and their internal travel motivation $(p<0.05)$. It was determined that significant differences originated from the sub-dimensions "Distancing", "Visiting" and "Prestige", which are the sub-dimensions of the internal travel motivation scale, that students and artisan-merchant were the groups that attached the most importance to the "Distancing" sub-dimension, that housewives and retirees attached more importance to the "Visiting" sub-dimension, and that the "Prestige" sub-dimension was the most important for artisan-merchant and student group. A significant difference was found between the external travel motivation scale and the occupational variables of the participants $(p<0.05)$. A significant difference was found between the "Popularity" sub-dimension of the external travel motivation scale and the occupational variables of the participants, and it was revealed that the occupational group that attached the most importance to this dimension consisted of retired individuals and the artisan-merchant group.

In the study conducted by De-Gen (2004), significant differences were found between the participants' occupational variables and their internal and external motivation for travel. Significant differences were determined between the occupational variables of the participants and the sub-dimensions of internal travel motivation scale, namely "Adventure and innovation", "Developing human relationships", "Appreciation of the natural scene and gaining knowledge." No significant difference was found in the dimension of "Prestige", and it was revealed that the group that attached the most importance to this dimension was the "Peasant-Farmer" group. In terms of external travel motivations, significant differences were determined between the sub-dimensions of "High-quality tourist resources" and "Information and availability of suitable facilities." According to a study conducted by Sert (2019), it was found that retired individuals had lower travel motivation than other individuals, and it was revealed that the occupational groups with the highest motivation consisted of "selfemployed" and "paid employee" participants. According to a study conducted by Yazıcioğlu and Akbulut (2016), no difference was found between participants' travel motivation and working status, and it was found that students' "Entertainment" motivation was higher than the motivation of other occupational groups.

As a result, no significant difference was found between the importance given to recreational activities in the destination choice and the demographic characteristics of individuals traveling to Kars on the Orient Express journey. It was revealed that the internal travel motivations differed in all the specified demographic characteristics. Besides, it was found that external travel motivations did not differ significantly only in terms of the income 
variable of individuals, and that there were significant differences in terms of other demographic variables.

It was determined that the groups that attached the most importance to recreational activities in their destination choice according to various variables were composed of male participants in terms of gender variable, single individuals between the ages of 18-24 in terms of age and marital status, and students in terms of occupation variable. This situation is thought to have stemmed from the fact that in the demographic distribution, $60 \%$ of the participants were male, $64.6 \%$ were single, and $41 \%$ were between the ages of $18-24$ and $41.2 \%$ were students.

It turns out that the variable groups that attached the most importance to the sub-dimensions of "Distancing" and "Experience-Discovery" among internal travel motivations consisted of female participants, individuals aged between 18-24, individuals with an income of 2,020 TL and below, and students. It was also determined that female participants, married individuals in terms of marital status, individuals aged 50 and over in terms of age variable, and housewives in terms of occupation attached more importance to the dimension of "Visiting." The 'Prestige' and 'Action' dimensions were attributed the most importance by male participants, individuals with an income level of 2,020 TL and below and 2,021 TL-3,000 TL in terms of income variable, and participants who were retired and artisan-merchant in terms of occupation variable.

In the light of the results revealed, it is recommended that this study, which examined the recreational activities in destination choice, internal and external travel motivations of individuals traveling to Kars with the Orient Express in terms of demographic variables, should be conducted on a larger sample group and comparatively analyzed in the national or international context.

Since the majority of the sample group consisted of young people and retired individuals, it is recommended to increase the number of special tours (e.g. cultural tours) for youth tourism and elderly tourism. To increase the touristic demand for the places that can be considered as an attraction factor, it is thought that organizing private tours to these areas may be important in the development of domestic tourism.

\section{References}

Aksu, H. S. (2020). Rekreasyon ve ihtiyaç kavramı. Içinde İ. Kayantaş M. Söyler (Ed.), Sporda Akademik Yaklaşımlar-6 (ss. 71-85). Ankara: Gece Kitaplığı.

Akyürek, S. and Köroğlu, A. (2017). Yerli turistlerin rekreasyon alan ve faaliyetleri hakkındaki görüşleri üzerine bir araştırma: Bodrum ziyaretçileri örneği. Journal of International Social Research, 10(54): 1065-1074.

Alghamdi, A. (2007). Explicit and implicit motivation towards outbound tourism: A study of Saudi tourists submitted. The University of Glasgow, School off Business and Management As A Thesis For Degree of Doctor of Philosophy In Marketing. Glasgow: Scotland.

Altunsoy, A. (2005). Kentsel tarihi çevre koruma (Kars üzerine bir inceleme).Yayınlanmamış Yüksek Lisans Tezi. T.C. Uludağ Üniversitesi, Sosyal Bilimler Enstitüsü, Kamu Yönetimi Anabilim Dalı. Bursa.

Demirel, M., Kaya, A., Tükel, Y., and Harmandar Demirel, D. (2021). The relationship between recreational awareness and satisfaction with life: The case of university students. Ambient Science. 8(1), 10-1

Andreu, L., Kozak, M., Avci, N. and Cifter, N. (2006). Market segmentation by motivations to travel: British tourists visiting Turkey. Journal of Travel \& Tourism Marketing, 19(1), 1-14. 
Antara, M. and Prameswari, Y. A. (2018). Push and pull factors of tourists visit the tourism destination of Bali, Indonesia. Journal of Tourism and Hospitality Management, $6(1), 112-120$.

Armutçu, F. (2018). Fiziksel aktivite amaçlı park ve rekreasyon alanlarının kullanımını etkileyen faktörlerin belirlenmesi. T.C. Batman Üniversitesi Sosyal Bilimler Enstitüsü Yüksek Lisans Rekreasyon Yönetimi Anabilim Dalı. Batman.

Atsiz, O., and Kizilirmak, İ. (2017). Mardin'in doğal ve kültürel çekiciliklerinin destinasyon pazarlaması kapsamında incelenmesi. Mukaddime. 8(1), 25-41.

Aydemir, C. (1993). Türkiye'de Cumhuriyet dönemi demiryolu ulaşımı ve bu konuda izlenen politikalar. Yayımlanmamış Doktora Tezi. T.C. Marmara Üniversitesi, Sosyal Bilimler Enstitüsü. Istanbul.

Aziz, Y. A., Hussin, S. R., Nezakati, H., Yusof, R. N. R. \& Hashim, H. (2018). The effect of socio-demographic variables and travel characteristics on motivation of Muslim family tourists in Malaysia. Journal of Islamic Marketing, 9(2), 222- 239.

Baloğlu, S. and Uysal, M. (1996). Market segments of push and pull motivations: a canonical correlation approach. International Journal of Contemporary Hospitality Management. 8(3):32-38.

Başarangil, İ., Altunel, M. C. and Tokatli, C. (2016). Trakya bölge halkının destinasyon yönelimlerindeki rekreasyonel etkinlik tercihlerinin demografik değişkenler açısından incelenmesi. Journal of Tourism and Gastronomy Studies, 4(4), 39-56.

Büyüköztürk, Ş., Kiliç Çakmak, E., Akgün, Ö., Karadeniz, Ş. and Demirel, F. (2012). Bilimsel araştırma yöntemleri. Pegem Yayınevi, Ankara.

Can, E. (2015). Boş zaman, rekreasyon ve etkinlik turizmi ilişkisi. İstanbul Sosyal Bilimler Dergisi, (10), 1-17.

Crompton, J. (1979). Motivations for pleasure vacation. Annals of Tourism Research, 6(4), 408-424.

Dann, G. (1977). Anomie, ego-enhancement and tourism. Annals of Tourism Research, Vol. 41. 84-194.

De-Gen, W. (2004). Push-pull factors in mountain resorts. Chinese Geographical Science, 14 (4) 368-376.

Demir, C. (2002). Turizm ve rekreasyon faaliyetlerinin olumsuz çevresel etkileri: Türkiye'deki milli parklara yönelik bir uygulama. Dokuz Eylül Üniversitesi İktisadi İdari Bilimler Fakültesi Dergisi, 17(2), 93-117.

Demir, M. (2013). Kars kent coğrafyası. Yayınlanmamış Doktora Tezi T.C. Atatürk Üniversitesi Sosyal Bilimler Enstitüsü Coğrafya Anabilim Dalı, Erzurum.

Demirci Orel, F. and Yavuz, M. C. (2003). Rekreasyonel turizmde müşteri potansiyelinin belirlenmesine yönelik bir pilot çalışma. Çukurova Üniversitesi Sosyal Bilimler Enstitüsü Dergisi, 11(11), 61- 76.

Doğaner, M. C. and Armağan, E. (2018). Seyahat bloglarının destinasyon seçimine etkisi. Pamukkale Üniversitesi Sosyal Bilimler Enstitüsü Dergisi, Sayı 30, 223-237.

Emre, C. (1992). Gençlik Turizmi Konferansı / Workshop'u. Anatolia: Turizm Araştırmaları Dergisi, 3 (3), 26-28.

Ercan, F. and Civelek, M. (2020). Rekreasyon faaliyetleri kapsamında etkinlik ve festivallerin destinasyon imajına etkisi. Türk Turizm Araştırmaları Dergisi, 4(1): 653664.

Ersoy S. and Güldemir, O. (2008). Üniversite öğrencilerinin boş zamanlarını değerlendirme faaliyetlerinin sosyoekonomik boyutu üzerine bir inceleme. 17. Ulusal Eğitim Bilimleri Kongresi.01-03. 1-12.

Eryilmaz, B. and Yücetürk, C. (2018). Genç turistlerin doğu ekspresi seferleri tercihlerinde instagram'in rolü. Journal of Tourism and Gastronomy Studies, 6(4), 210-228. 
Ferreira, D., Perks, S. and Oosthuizen, N. (2015). Influence of ethnicity and family status on outboun destination choice: A South African perspective. International Business \& Education Conferences, June 7-11, 421.-227.UK: London.

Field, A. (2009). Discovering statistics using spss (3rd ed.). London: Sage

Gözen, E. (2019) Rekreasyon Yönetimi Bölümü Lisans Öğrencilerinin Rekreasyon Kavramına İlişkin Metaforik Algıları. Stratejik ve Sosyal Araştırmalar Dergisi, 3(3), 397-416.

Gümüş, H. (2012). Fiziksel aktivite için park ve rekreasyon alanlarına gelen kullanıcıların mekân seçimini ve fiziksel aktiviteye katılımını etkileyen faktörler. Yüksek Lisans Tezi T.C. Gazi Üniversitesi Sağlık Bilimleri Enstitüsü Beden Eğitimi ve Spor Anabilim Dalı Spor Yönetim Bilimleri Programı. Ankara.

Gümüş, H., Alay, Ö. S. and Karakılıç, M. (2017). Fiziksel aktivite için park ve rekreasyon alanlarına gelen kullanıcıların mekân seçimini ve fiziksel aktiviteye katılımını etkileyen faktörler. Spormetre Beden Eğitimi ve Spor Bilimleri Dergisi, 15(1), 31-38.

Hanqin, Q. Z. and Lam, T. (1999). An analysis of mainland Chinese visitors' motivations to visit Hong Kong. Tourism Management, 20 (5). 587-594.

Jang, S., S. and Wu. C. M. E (2006). Seniors' travel motivation and the influential factors: an examination of Taiwanese seniors. Tourism Management, 27(2), 306-316.

Jensen, J., M. (2011). The relationships between socio-demographic variables, travel motivations and subsequent choice of vacation. 2nd International Conference on Economics, Business and Management. Prague, Czech Republic.

Jondeau, E. and Rockinger, M. (2003). Conditionalvolatility, skewness, and kurtosis: Existence, persistence, and comovements. Journal of Economic Dynamics \& Control, 27, 1699- 1737.

Karadaşli, H. (2019). Motivasyon temelli kültür turisti tipolojileri: Diyarbakır'a gelen yerli turistler üzerine bir araştırma. Yayınlanmamış Yüksek Lisans Tezi. Batman Üniversitesi Sosyal Bilimler Enstitüsü. Batman.

Karstanhavadis. (2021). http://www.karstanhavadis.com/kars-kalesinden-kartpostallikgoruntu-1696h.htm Date of Access: 10.02.2021.

Kasim, A., Dzakiria, H., Park, C., Nor, N. A. M., Mokhtar, M. F. and Rashid Radha, J. R. (2013). predictors of travel motivations: the case of domestic tourists to island destinations in Northwest of Malaysia. Anatolia. 24 (2).188-205.

Kaya, F. (2007). Bartın kent halkının rekreasyonel eğilim ve taleplerinin belirlenmesi üzerine bir araştırma. Yayınlanmamış Yüksek Lisans Tezi. T.C. Ankara Üniversitesi, Fen Bilimleri Enstitüsü, Peyzaj Mimarlığı Anabilim Dalı, Ankara.

Keleş, Y. (2015). Seyahat acentacılığı ve tur operatörlüğü (1. Bask1). Grafiker Yayınları, İstanbul.

Kervankiran, İ. and İlban, K. (2019). Türkiye'den turizm amaciyla yurtdışına giden kadınların seyahat motivasyonları. 20. Ulusal Turizm Kongresi. 542-546. Eskişehir.

Khuong, M. N. and Ha, H. T. T (2014). The influences of push and pull factors on the international leisure tourists' return intention to Ho Chi Minh City, Vietnam--A mediation analysis of destination satisfaction. International Journal of Trade, Economics and Finance, 5(6), 490-496.

Kim, S. S., Lee, C. K. and Klenosky, D. B. (2003). The influence of push and pull factors at Korean national parks. Tourism Management, 24(2), 169-180.

Kırzıoğlu, F. (1953). Kars tarihi I. cilt. Iş11 Matbaası, İstanbul.

Korkusuz, T. (2019). Kars ilindeki turizm varlıklarının küreselleşmenin etkisi ile incelenmesi ve cbs analizi. Yayınlanmamış Doktora Tezi. T.C. Atatürk Üniversitesi Sosyal Bilimler Enstitüsü Coğrafya Anabilim Dalı, Erzurum.

Kozak, N., Kozak, M. A., and Kozak, M. (2015). Genel turizm. Ankara: Detay Yayıncılik. 
Li, F. S. and Qi, H. (2019). An investigation of push and pull motivations of C hinese tourism doctoral students studying overseas. Journal of Hospitality, Leisure, Sport \& Tourism Education, 24, 90-99.

Li, M., Wen, T., and Leung, A. (2011). An exploratory study of the travel motivation of Chinese female outbound tourists. Journal of China Tourism Research, 7(4). 411-424.

Mohsin, A. (2008). Analysis of Chinese travellers' attitudes toward holidaying in New Zealand: The impact of socio-demographic variables. Journal of Hospitality \& Leisure Marketing. 16.1-2. 21-40.

Özdemir, A. S. (2013). Motivasyonel ve demografik faktörlerin rekreasyonel olanaklara dayalı yapılan destinasyon tercihleri üzerine etkisi. T.C. Gazi Üniversitesi Sağlık Bilimleri Enstitüsü. Ankara.

Özdemir, A. S., Büyüköztürk, Ş. and Karaküçük, S. (2016). Explaining destination choices based upon recreational opportunities through intrinsic and extrinsic travel motivations Rekreasyonel olanaklara dayalı yapılan destinasyon tercihlerinin içsel ve dışsal seyahat motivasyonlarıyla açıklanması. Journal of Human Sciences, 13(2), 3002-3021.

Öztürk, Y. and Şahbaz, R. P. (2017). Algılanan destinasyon imajının tekrar ziyaret niyeti ve tavsiye davranışı üzerine etkisi: Ilgaz Dağı Milli Parkı'nda bir araştırma. Journal of Tourism and Gastronomy Studies, 5(2), 3-21.

Öztürk, Y. and Tecimen, M. (2017). Halkın boş zaman değerlendirme alışkanlıkları: Çankırı örneği. Yönetim, Ekonomi ve Pazarlama Araştırmaları Dergisi, 1(2) 1-14.

Pattanapokinsakul, K. and Phakdee-Auksorn, P. (2015). Analysis of push and pull travel motivation of foreign tourist to localmarkets: A case study of Phuket, Thailand. Journal of International and Thai Tourism, 11(2). 44-63.

Said, J. and Maryono. M. (2018). Motivation and perception of tourists as push and pull factors to visit national park. In E3s Web of Conferences (Vol. 31, P. 08022). Edp Sciences.

Sert, A. N. (2019). Üçüncü yaş yerli turistlerin seyahat kısıtları ve motivasyonları üzerine bir araştırma. Selçuk Üniversitesi Sosyal Bilimler Enstitüsü Dergisi, (42), 200-211.

Seyanont, A. (2017). Travel motivation and intention to revisit of European senior tourists to Thailand. Universal Journal of Management, 5(8). 365-372.

Subadra, I. N., Sutapa, I. K., Artana, I. W. A., Yunı, L. H. K. and Sudiarta, M. (2019). Investigating push and pull factors of tourists visiting Bali as a World tourism destination. Journal of Multidisciplinary Educational Research, 8(7). 253-269.

Syzdykova, A., Abubakirova, A., and Bingöl, Z. (2018). Gençlik Turizminin Küresel Düzeyde Değerlendirilmesi. Gençlik Araştırmaları Kongresi Kongre Bildiri Kitabı. 97-106. 27 Haziran - 01 Temmuz 2018 Nahçivan.

Talay, İ., Kaya, F., and Belkayali, N. (2010). Sosyo-ekonomik yapının rekreasyonel eğilim ve talepler üzerine etkisi: Bartın kenti örneği. Coğrafi Bilimler Dergisi/Turkish Journal of Geographical Sciences, 8(2).147-156.

Tangeland, T., Aas, O. and Odden, A. (2013). The socio-demographic influence on participation in outdoor recreation activities-Implications for the Norwegian domestic market for nature-based tourism. Scandinavian Journal of Hospitality and Tourism, 13(3), 190-207.

TCDD (2018). 2017 faaliyet raporu. TCDD Taşımacılık Aş Yayın No: 2018-1.

Toprak, L., Serçek, S. and Serçek, Özaltaş, G. (2014). Öğrencilerin üniversiteden rekreasyon aktiviteleri konusunda beklentileri. VII. Lisansüstü Turizm Öğrencileri Araştırma Kongresi, 04-05.

Türker, N., Ölçer, H., and Aydin, A. (2016). Yerel halkın serbest zaman değerlendirme alışkanlıkları: Safranbolu örneği. Karabük Üniversitesi Sosyal Bilimler Enstitüsü Dergisi. 6(1) 49-62. 
Woyo, E., Slabbert, E., and Saayman, M. (2019). Do socio-demographic characteristics influence destination attractiveness perceptions after political turmoil: the case of Zimbabwe? African Journal of Hospitality Tourism and Leisure. 8(3). 1-20. 1-20.

Yazicioğlu, İ. and Akbulut, B. (2016). Yabancı turistlerin seyahat motivasyonlarının demografik özellikleri açısından analizi: Ankara örneği. Journal of Human Sciences. 13(2). 3231-3241.

Yılmaz, G. (2018). Üniversite gençliğinin turizme bakış açısı: İstanbul Arel Üniversitesi Örneği. OPUS Uluslararası Toplum Araştırmaları Dergisi, 8(15), 1516-1538.

Zhang, W. (2009). The motivations, constraints and decision-making of beijing outbound tourists. Doctor's Degree University of Waikato, Department of Tourism and Hospitality Management. Hamilton, New Zelland.

\section{Author biography}

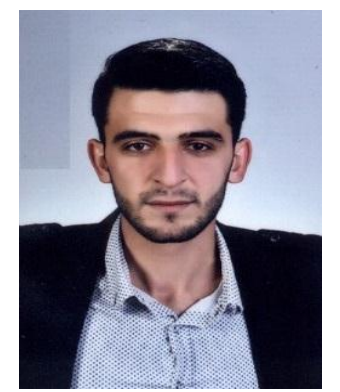

Alper KAYA completed his undergraduate education at Gazi University Faculty of Tourism, Department of Recreation Management between 2013-2017. He completed his master's degree in Necmettin Erbakan University, Institute of Social Sciences, Department of Recreation Management in 2020. He started his doctorate in the same year and has various studies in areas such as recreation, tourism and sports. He has been working as a research assistant at Necmettin Erbakan University since 2019.

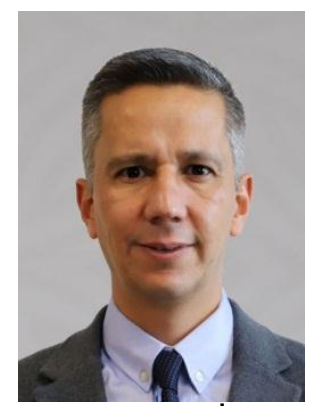

Mehmet DEMIREL completed his undergraduate degree from Hacettepe University, School of Sport Sciences and Technology, Department of Sport Sciences and Technology between 1998-2003. Between 2003-2005, he completed his master's degree in the Department of Physical Education and Sports at Gazi University and started his doctoral education in the same year. He completed his doctorate in 2009. Between 2005-2007, he worked as a research assistant at Dumlupınar University, Department of Physical Education Teaching. Later, he worked as a research assistant at Gazi University between 2007-2009. In 2011, he started working as an assistant professor at Dumlupinar University. He became associate professor at the same university in 2017. He has been working as associate professor at Necmettin Erbakan University, Faculty of Tourism, Department of Recreation Management since 2018. He has studies in recreation, tourism and sports fields. 